\title{
Расчёт цилиндрической части металлокомпозитного баллона давления
}

\section{Calculation of the cylindrical part of a metal-composite pressure vessel}

\section{Б. С. Сарбаев, С. Чжан}

Московский государственный технический университет

им. Н. Э. Баумана, Россия, Москва

\author{
B. S. Sarbayev, X. Zhang \\ Moscow Bauman State Technical University, \\ Russia, Moscow
}

Поступила в редакцию 01.02.2021, принята к печати 05.02.2021

\section{Абстракт}

В статье предлагается способ расчёта напряжений и деформаций в цилиндрической части металлокомпозитного баллона давления с несущим металлическим лейнером, усиленным кольцевыми композитными слоями. Для металла предлагается применять определяющие соотношениях теории пластичности изотропного тела, основанной на поверхности нагружения Треска-Сен-Венана. Рассмотрен случай линейного упрочнения. Для волокнистого композита используется нитяная модель. Выведены расчётные зависимости. В численном примере полученные с их помощью результаты сравниваются с результатами на основе теории течения Прандтля-Рёйсса. Также предлагаются расчётные зависимости для определения толщин стенки лейнера и композитного слоя, основанные на гипотезе равнонапряжённости металлического лейнера.

\section{Abstract}

A method for calculation of stresses and strains in the cylindrical part of a metal-composite pressure vessel with a carrying metal liner reinforced with circumferential composite layers is proposed. Constitutive equations of the theory of plasticity of an isotropic solid based on the Tresca-Saint-Venant yield surface is proposed to apply. The case of linear hardening is considered. A netting model is used for the fiber composite. The calculation relations are derived. In the numerical example the results, obtained with their help are compared with the results based on the Prandtl-Reuss flow theory. The calculated relations for determining the wall thickness of the liner and the composite layer based on the hypothesis of the equal-stressed state of the metal liner are also proposed.

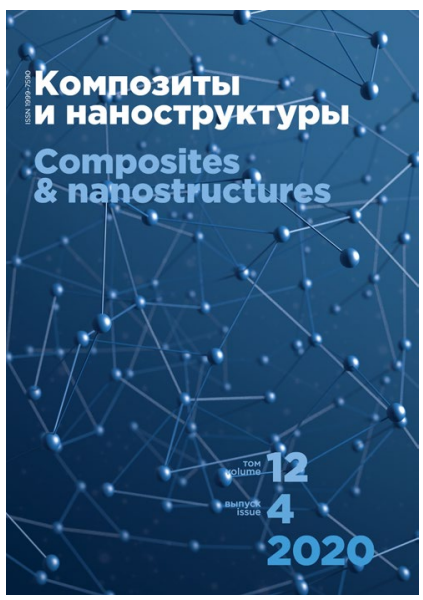

